\title{
Aprenda como criar um meio corporativo criativo ${ }^{1}$
}

\author{
Learn how to create a creative corporate environment
}

\section{Deise Cavignato}

Mestranda em Comunicação, pela Universidade Municipal de São Caetano do Sul - USCS; bolsista do Programa de Demanda Social da Coordenação de Aperfeiçoamento de Pessoal de Nível Superior - Capes/DS.

Os norte-americanos Bill Capodagli e Lynn Jackson fundaram, em 1993, a Capodagli Jackson Consulting, e trabalham com consultoria para diversas empresas. A filosofia empresarial criada por ambos é baseada nas inovações organizacionais das companhias Disney e Pixar e, por isso, fazem uso do slogan "sonhar, acreditar, ousar e fazer. O livro Nos bastidores da Pixar - lições do playground corporativo mais criativo do mundo aborda como a inovação no meio profissional pode trazer benefícios à empresa, incentivando a diversão entre os funcionários.

O livro, de 183 páginas, conta como Ed Catmull, cofundador da Pixar e atual presidente dos Estúdios de Animação Pixar e Disney, e Alvy Ray Smith, também cofundador da Pixar, criaram o estúdio. O começo da Pixar ocorreu com a contratação de John Lasseter, atual gerente-executivo de criação dos dois estúdios. Com a saída de Lasseter da Disney, porque achavam que a criatividade dele era muita, mas os custos para produzi-las também, Catmull \& Smith abocanharam a oportunidade e iniciaram a abertura do estúdio. Em nenhum momento do livro fala-se da Disney que comprou a Pixar, mas, ao longo do texto, subentendese que a Disney estava perdendo espaço para o novo concorrente e, com a ameaça, a compra foi iminente.

A publicação tem quatro partes, divididas em 13 capítulos. Antes da primeira parte, três capítulos explicam o mote de toda a leitura: o importante é saber olhar o mundo como se fosse uma criança dando asas aos sonhos. Os autores enfocaram a prioridade de uma organização ser inovadora assim como a famosa rede de fast-food (McDonald's), criada em 1912, ou Henry Ford com a linha de montagem de automóveis (Ford). São dadas também dicas para a criatividade aflorar como remover as barreiras entre os processos e assistir ao que irá acontecer, por exemplo. Há possibilidade de redefinir o seu produto ou serviço? Por que não montar um cenário diferente? Ou recrute os funcionários em um lugar fora do habitual para ver como ele se comporta.
A primeira parte, "Sonhe como uma criança", conta como foi a realização de um sonho: criar os estúdios da Pixar. Uma das mensagens mais esclarecedoras é brincar de seguir o líder. "Em vez de promoverem um ambien-

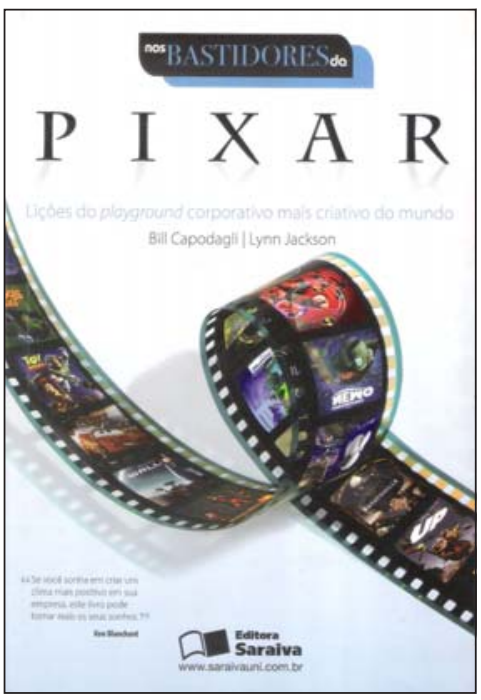
te de pensadores criativos e automotivados, eles (os líderes) assumem o papel de flautistas feiticeiros que levam os seguidores a se afogarem em um oceano de regras, regulamentos e processos corporativos". (p. 45) A Pixar brinca de seguir o líder com Walt Disney, já que seus criadores se espelharam na companhia para criar a sua própria. O clima da Pixar é interativo, as placas de informações são coloridas e engraçadas, os funcionários podem jogar pebolim e nadar em uma piscina olímpica. A quantidade de diversão significa o quão divertido será fazer o filme e assistir a ele também. Além da automotivação, os trabalhadores têm a liberdade de se comunicar com qualquer pessoa da empresa, independentemente do nível hierárquico, criando confiança e respeito mútuo.

"Acredite em seus colegas" é a segunda parte e aborda o tratamento dos subordinados para com os gerentes. "Mantenha o foco em conquistá-los para que abracem os seus sonhos" (p. 73), pois o sujeito pode deixar o sonho de uma vida inteira escapar. "Atreva-se a pular na água e fazer ondas" é outra parte do livro, que exibe experiências que parecem ser fracassadas, mas nem sempre são. Os autores dão exemplos da máquina de fax, que não foi bem aceita em 1840, e de Vincent Van Gogh, que só vendeu uma tela em toda a sua vida. Esta é a cultura de incentivar a correr riscos. Capodagli \& Jackson listaram " 41 coisas bacanas para liberar a imaginação" (p. 97), dentre elas, visitar um museu de arte, incentivar espaços individuais

\footnotetext{
${ }^{1}$ CApodagli, Bill \& JaCkson, Lynn. Nos bastidores da Pixar - lições do playground corporativo mais criativo do mundo. Tradução de Maria Amália Bernardi. São Paulo: Saraiva, 2010. 184p.
} 
Aprenda como criar um meio corporativo criativo

de trabalho criativo, perguntar "e se..." e "por que não?" e contratar alguém que seja completamente o oposto a quem efetua as contratações.

"Libere seu potencial de criança" é a quarta e última parte do livro e que também oferece dicas essenciais para criar um playground corporativo. Improvisar, fazer um "algo mais", treinar, divertir-se e brincar. O ideal é inovar, e não imitar. Por isso, o livro traz este ponto de partida para que as empresas sejam mais dinâmicas e flexíveis. Os autores terminaram mostrando que mais empresas já seguem essas dicas como o Google e a Nike.
O livro, que no Brasil foi publicado pela Saraiva, dá muitas informações úteis a quem quiser ser um bom líder. É como se fosse um texto de autoajuda para criar uma empresa diferente ou, até mesmo, apenas para mudar o ambiente de uma empresa que já existe há décadas e que ainda utiliza ideias ultrapassadas para se relacionar com funcionários e clientes. Vale a pena ler a fim de se entender melhor o meio corporativo criativo, que precisa crescer muito. A obra é capaz de motivar mudanças em organizações e empresas que necessitam de uma atualização no dia a dia, e o ponto de partida pode ser a leitura do Nos bastidores da Pixar. 